Original Paper http://ajol.info/index.php/ijbcs http://indexmedicus.afro.who.int

\title{
Ethnobotanical study of cultivated yellow nutsedge, (Cyperus esculentus L.) in Burkina Faso
}

\author{
Saïdou YAMWEMBA ${ }^{1 *}$, Nerbéwendé SAWADOGO², Mahamadi Hamed \\ OUEDRAOGO $^{3}$, Oble NEYA ${ }^{2}$, Zakaria KIEBRE ${ }^{1}$, Romaric Kiswendsida NANEMA ${ }^{1}$ \\ and Mahamadou SAWADOGO ${ }^{1}$
}

\author{
${ }^{1}$ Genetics and plant breeding team, Biosciences laboratory, University Joseph KI-ZERBO, 03 BP 7021 \\ Ouagadougou 03, Burkina Faso. \\ ${ }^{2}$ Head RC. Ecosystem Change \& Ecosystem Services WASCAL - Competence Center 06 BP 9507 \\ Ouagadougou 06, Burkina Faso. \\ *Corresponding author; E-mail: syamwemba@gmail.com
}

\begin{abstract}
The yellow nutsedge, Cyperus esculentus L. is an herbaceous species whose tubers are the edible parts. The tubers are very popular with children, and can be eaten raw, fried or after processing into a drink (Horchata). However, it does not exist in Burkina, a centralized collection and studies on the genetic variability, the sociocultural and economic aspects of this species. In order to identify the morphotypes and to welcome the peasant knowledge on the management of the, yellow nutsedge, a prospection followed by collection of tubers were carried out in the main areas of production of this crop. A total of 22 villages in eight districts were visited and 108 accessions of tubers were collected. It emerges from this study that the cultivation is mainly practiced by women (97\% of farmers). The cultivated yellow nutsedge is adapted to drought and to several types of soil. In addition, farmers classify the tubers according to their shape and size. Thus, the spherical tubers are qualified as "small tubers the non-spherical tubers as" large tubers. The number of tubers produced per foot varies from 20 to 60. Farmers use phenotypic characters, sexual dimorphism and ethnicity to name accessions for sweet peas. Vernacular names and methods of producing yellow nutsedge vary by region and ethnicity. According to the respondents, $84.34 \%$ think that the nut is of Burkinabé origin, 9.26\% Ghanaian, $1.85 \%$ from Mali and 5.35\% have no answers. There is great diversity in local knowledge and accessions collected in Burkina.
\end{abstract}

(C) 2020 International Formulae Group. All rights reserved.

Keywords: Ethnobotany, tubers, accessions, morphotypes.

\section{INTRODUCTION}

Yellow nutsedge, (Cyperus esculentus L.) is a perennial herbaceous type $\mathrm{C} 4$ with clonally growth which belongs to the family of Cyperaceae (Judd et al., 2002). It is characterized by trifocal stems, tristic leaves, the absence of ligules in general and closed sheaths (Defelice, 2002). Currently, it is still cultivated for food and medicinal purposes in Southern Europe, Africa and Asia; (Bamishaiye and Bamishaiye, 2011; PascualSeva et al., 2013). The tubers contain about $50 \%$ carbohydrates including sucrose and starch, $22 \%$ fat and 6 to $7 \%$ protein. It has been domesticated in many regions of the world such as Spain in the Valencia region. It is 
widely encountered in California, Ghana, Nigeria, Niger, Mali, Côte d'Ivoire, and Burkina Faso where it is called "sweet pea" or "tchoncon" in the local language. In fact, the tubers contain essential nutrients for health. It fights hypertension and cholesterol, prevents cardiovascular problems, cancer and constipation. In addition, in nutrition, it is rich in proteins, fats, carbohydrates, mineral salts, vitamins $E$ which is an antioxidant and vitamin C. It can be eaten raw, transformed into milk and oil (for consumption and cosmetics), in dough, in biscuit and in supplements for infants. Despite these undeniable assets, there still does not exist in Burkina, a centralized collection and very little information is available on its zone and the extent of its production, the peasant management methods of culture, as well as its technical itinerary of production, variability and genetic diversity. Only some rare information on local biochemical composition and information carried out for the most parts on international collections is available. In order to constitute a national collection and to identify the various existing morphotypes as well as to collect peasant knowledge on the management of the nutcracker, a prospection-collection of tubers and an ethnobotanical survey were carried out in the main zones of production of yellow nutsedge in Burkina Faso.

\section{MATERIALS AND METHODS \\ Study zone}

Yellow nutsedge is a neglected crop which is not produced everywhere in Burkina. There are no statistics concerning its production. Due to the lack of control over its cultivation area, prior information was collected from agents of the decentralized services of the Ministry of Agriculture in 2016. The choice of the villages prospected was thus made with the assistance of these agents who are in contact with producers. Prospectingcollection was then carried out in December 2017 in eight municipalities and 22 villages in five provinces distributed in the Hauts-bassins, Southwest and Cascades regions (Figure 1). All these localities are located in the Sudanian zone of Burkina Faso.

\section{Ethnobotany surveys}

Data on the management of the nutsedge was collected from the farmers in the main production areas through a semistructured survey. Thus, semi-structured direct interviews were carried out with 91 producers of sweet peas. The results made it possible to fill in a file. The information collected relates to the use of the nutsedge, the origin of the seed, the local appellations, the cultivar cycles, the soil preparation techniques, the techniques of tending the fields and harvesting, the mode of tubers treatment before sowing and after harvest, as well as methods of storing tubers.

\section{Statistical analysis of the data}

Quantitative and qualitative data (cultivar names and origin, trial set-up techniques and plot maintenance) were synthesized. They were then recorded in the Excel 2007 file and subsequently used to generate the tables and figures. The XLSTAT 2016 software was used to perform analyses of variance.

\section{RESULTS}

\section{Cultivation area of Cyperus esculentus $\mathbf{L}$.}

The cultivation areas of Cyperus esculentus L. identifier covers three regions, namely, the Hauts-bassins, Cascades and Southwest regions. According to the monograph of the three regions in 2011, they are limited to the North by the Boucle du Mouhoun region, to the West by the Republic of Mali, to the South by the Republic of Côte d'Ivoire, to the East by the Republic of Ghana and the Central West region. The production area covers a total area of $60,221 \mathrm{~km}^{2}$, or $22.1 \%$ of the national territory. The Sudanian zone, with rainfall varying between 900 and 1,200 $\mathrm{mm}$ of water, is the main sweet pea production zone in Burkina Faso. However, 100\% of the producers affirmed that the yellow nutsedge tolerates drought in the same degree as the other crops such as corn, millet, sorghum and groundnuts of the locality. Also, for them this culture does not like very wet soils. In addition to them, this crop is adapted to all types of soil but prefers sandy soils. 


\section{Distribution of accessions of Cyperus esculentus L. \\ Breakdown by production area}

The accessions of the prospecting collection were distributed in eight communes (Koloko, Kangala, Ouéléni, Mangodara, Banfora, Ouéléni, Kanyangda, Lorépeni and Tiankoura) and five provinces (Kénédougou, Sindou, Banfora, Gaoua and Bougriba). The percentage of accessions is $40.75 \%$ in the Hauts-bassins region, $30.55 \%$ in the Cascades region and $28.70 \%$ in the Southwest region (Table 1). All these localities are located in the Sudanian zone of Burkina Faso.

\section{Distribution by ethnic group and gender}

The Sénoufos, Gouins, Dogossès, Gans and Lobis are the ethnic groups that produce sweet peas in Burkina Faso. Among the 108 accessions in the collection, 58 accessions belonged to Sénoufos, 12 accessions to Gouins, seven accessions to Dogossès, 14 accessions to Gans and 17 accessions to Lobis (Figure 2). The yellow nutsedge culture is practiced exclusively by women in the Southwest, but in the Hauts-bassins and Cascades men are more and more interested in the culture. This culture is practiced by $97 \%$ of women as against $3 \%$ of men.

\section{Variations and criteria for peasant names}

The vernacular names of the yellow nutsedge vary by location and ethnicity, as shown in Table 2 . Thus, the vernacular names of the municipalities of Kénédougou and Léraba are identical. In these provinces, the yellow nutsedge tuber is called "meniquis", the spherical tubers are called "small tuber" or "minquini" and the non-spherical tubers "large tuber" or "mounquini". The Goins at Banfora, producers have black tubers which are considered to be spherical and called "sluggish slime". They also have yellow tubers, the spherical of which are called female tubers or "mou tiama" and the non-spherical tubers called of male tuber or "mou balma". Similarly, according to Kabré et al. (2019), farmers use colour to distinguish morphotypes of Hibiscus cannabinus L.

At Mangodara among the Dogosse, the producers believe that they have a single nutcracker morphotype called "Hoossa". In Lorepenie, the Gans distinguish several morphotypes but in general, the tuber is called "cognon". The non-spherical tubers are called "large tuber" or "cotama" and the spherical tubers are called "small tuber" or "cocourou". In Gaoua, the tuber is called "pwan", the nonspherical tubers are called "large tuber" or "ganpwan" and the spherical tubers, "small tuber" or "lobipwan". Banfora producers use color and gender as criteria for naming sweet peas. Those in Tiankoura use ethnicity in the denomination and the rest of the producers use the length of the tuber for this denomination.

\section{Places of production and cultivation techniques}

The nutsedge is generally cultivated in the bush $(75 \%)$, in the Hauts-bassin, in the Cascades and in a part of the Southwest at Lorepenie. However, in Tiankoura, part of the Southwest region, the nutcracker cultivation is carried out in hut fields $(17.7 \%)$. While in Mangodara, the fields are located in the shallows $(7.29 \%)$. Most of the yellow nutsedge producers use monoculture $(85.42 \%)$ from which some opt for agroforestry by often associating woody species (mango, cashew) in their farming. However, in Lorepeni, the Gans $(14.58 \%)$ practice the cultural rotation, the producers periodically alternate the cultivation of the nutcracker with those of groundnuts, cowpeas and sorghum. Apart from the uses of tubers, agricultural practices in the three regions can be summarized in four main stages, namely, soil preparation, sowing, harvesting and storage of tubers.

\section{Soil preparation and sowing method}

Land preparation varies from region to region. In the Hauts-bassin region, it consists of creating boards. In Cascades, the soil preparation technique varies according to the provinces. In fact, in the province of Léraba bordering Kénédougou, the peasants use planks while in the Banfora districts and Mangodara, they use ridges for the cultivation of nutsedge. Finally, in the South-West, in the municipality of Lorépéni and Tiankoura respectively in the province of Poni and Bougriba, the cultivation of nutsedge is carried 
out on specific boards. Indeed, the planks of these very tall farmers do not completely cover the entire field like that of the previous regions, the planks are drained perpendicularly in an $\mathrm{E}$ shape.

Before sowing, the tubers are soaked in water for 24 to 48 hours to select good quality tubers. Sowing of the nutcracker tubers which takes place in mid-August (75\%) or in mid-July (25\%) according to the producers, in the three regions have many similarities but there are some differences. In general, the producers sow using the fingers, they introduce one tuber per pocket and the distance between the pockets is very small, 10 to $15 \mathrm{~cm}$. This stage is marked by the peculiarity of the mode of sowing of the producers of Kénédougou who sow the tubers using the fingers backwards because if they trample the sowing, the tubers will germinate on their feet or that can cause death. In addition, in Fellini in the district of Oueleni, men who have just been interested in cultivation use the jet as a sowing method. During the reproductive cycle, the nutcracker does not benefit from weeding, but the producers use NPK and urea to increase the yield.

\section{Harvest}

The harvest of cultivated nutsedge arouses curiosity as much on the athleticism of the producers as on their ingenuity. Growers go through several stages when harvesting nutsedge: first, they burn the aerial vegetative part consisting mainly of leaves, stems and umbel, then they break up the clods of earth from the board with a large wood. Then, with the help of the hoes they all group the field, which is now made up of very fine particles, into piles of sand. Finally, using a nutsedge sieve, they sift the batches of sand to retain the tubers (Figure 3), but this harvest has disparities within the nutsedge producing regions of Burkina Faso.

In the Hauts-bassins, the sieve is an iron table about $0.5 \mathrm{~m}$ high with holes in the upper part. The women collect the batches of sand using hoes, from the ground to the sieve. After sifting, the tubers trapped with the residue and pieces of stones which are then rubbed together to get rid of the leaf scales.
In the Cascades, in Mangodara, the nutsedge producers do not use a sieve, they collect the tubers using a pickaxe like the peanut harvest. However, in Banfora, the producers harvest either fresh or dry. Fresh harvesting consists of pulling and tapping the nuts with the hoes and then, using baskets, they sift the fallen soil to trap the tubers. These fresh, unsweetened tubers are kept for 3 days for fermentation. According to the growers, after this process, the yellow nutsedge tubers will have a sweet taste. Dry harvesting is similar to that of Mangodara, that is to say, using picks, or that of yellow nutsedge which uses a sieve.

In the Southwest, the sieve is made of wood; it is rectangular in shape, containing a mesh surrounded by a board. The women collect the sand batches with a dish, from the ground to the sieve. After sifting, the tubers trapped with the residue and pieces of stones are then rubbed together to get rid of the leaf scales.

\section{Post-harvest treatment of yellow nutsedge and conservation}

The method of preservation is a very important step in the production of nutsedge nuts as well as post-harvest treatment (Figure 4). Preservation generally consists of several stages. In Mangodara, the nutsedge tubers are winnowed by wind to remove unwanted dust and sediments, whereas in the Hauts-bassins, the tubers are winnowed by water, the tubers are washed in several successive waters before being stored in bags for preservation. In Banfora, after harvesting, the farmers wash and dry the tubers in the sun, they add sand before storing in granaries. Finally, in the Southwest, the tubers are washed carefully, dried and mixed with ashes before being stored in jars. According to Sawadogo et al. (2014), on sweet grain sorghum, storing seeds in airtight enclosures can suffocate the larvae of the pest.

\section{Use of nutsedge}

Nutsedge tubers have several uses in the production area in Burkina Faso. Nutsedge tubers are used locally for socio-cultural, food and medicinal purposes and are preserved as seeds. Yellow nutsedge also provide substantial income for women. Nut tubers are 
sold to small traders in each village or sold in large markets such as Banfora, Bobo, and Gaoua.

Nutsedge tubers are consumed in their raw state. Others, on the other hand, immerse the tubers in water for a few hours, before eating; they can add sugar or salt. In the province of Bougriba in Tiankoura, when a breastfeeding mother dies, the nut sedge tubers are crushed or crushed, associated with water, the whole will give milk that will validly replace breast milk. On the medicinal level, yellow nutsegde are used to treat sexual weakness, constipation and problems with milk secretion in breastfeeding women.

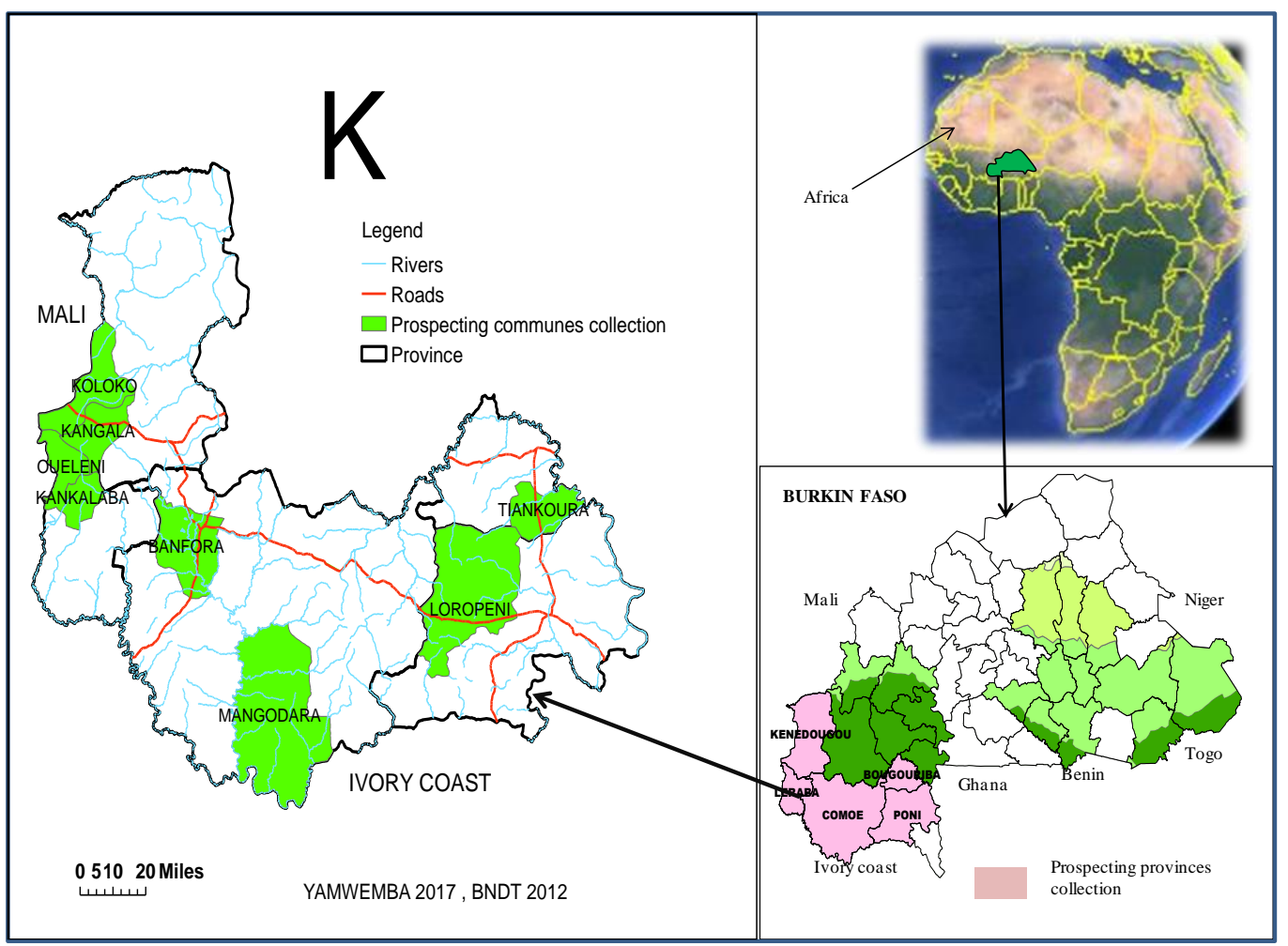

Figure 1: Map of prospecting sites for collecting sweet peas Cyperus esculentus L.

Table 1: Distribution of accessions by production areas.

\begin{tabular}{lllll}
\hline Regions & Provinces & Districts & Number of accessions & Percentage \\
\hline Hauts-bassin & Kénédougou & Koloko & 19 & $40,75 \%$ \\
& & Kangala & 25 & \\
Cascades & Comoé & Mangodara & 07 & $30,55 \%$ \\
& & Banfora & 12 & \\
& Léraba & Ouéléni & 08 & \\
\multirow{3}{*}{ South west } & & Kankalaba & 06 & $28,70 \%$ \\
& Poni & Lorépéni & 14 & \multirow{2}{*}{ Total } \\
& Diébougou & Tiankoura & 17 & $100 \%$ \\
\hline
\end{tabular}




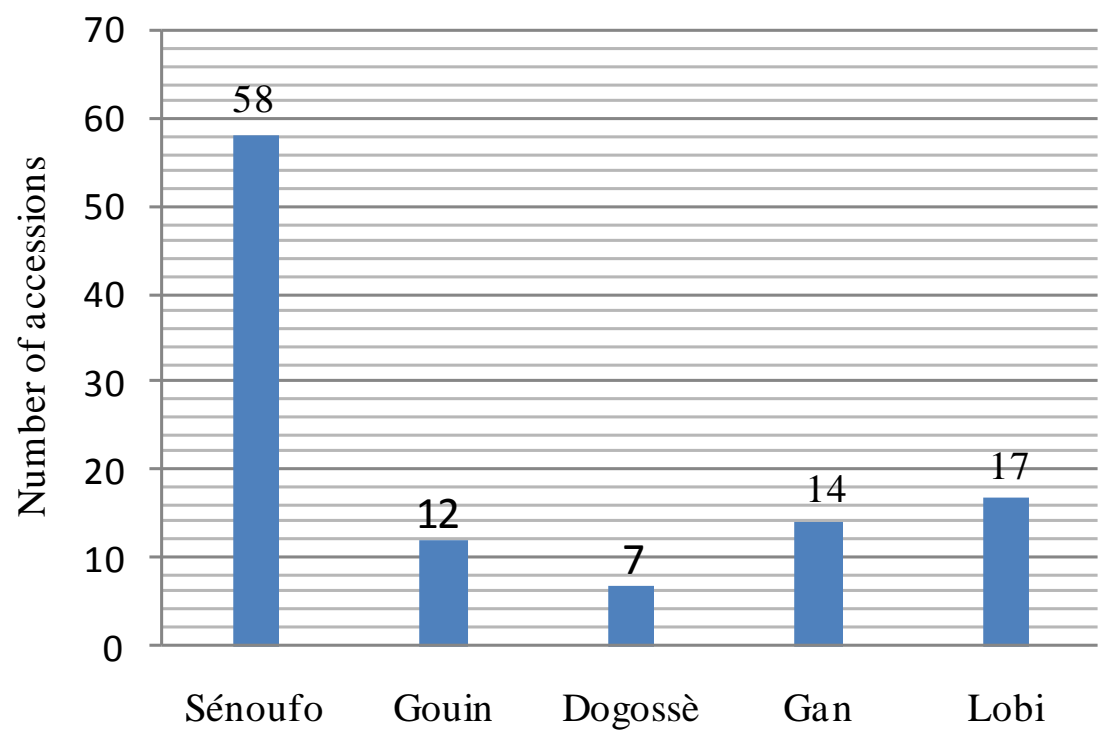

Accessions

Figure 2: Distribution of accessions according to ethnic groups.

Table 2: Distribution of names according to ethnicity.

\begin{tabular}{lllll}
\hline Ethnic & Groups local names & Tuber shape & Colors & Names \\
\hline \multirow{2}{*}{ Sénoufos } & \multirow{2}{*}{ Meniquis } & Spherical & Yellow & Minquini \\
& & Non-spherical & Yellow & Mounquini \\
\multirow{2}{*}{ Sénoufos } & \multirow{2}{*}{ Meniquis } & Spherical & Yellow & Minquini \\
& & Non-spherical & Yellow & Mounquini \\
\multirow{2}{*}{ Gouin } & \multirow{2}{*}{ Mouigua } & Spherical & Black & Mou bulilé \\
& & Spherical & Yellow & Mou tiama \\
\multirow{2}{*}{ Dogossè } & \multirow{2}{*}{ Hoossa } & Non-spherical & Yellow & Mou balma \\
& & All shapes & Yellow & Hoossa \\
Gan & Cognon & Spherical & Yellow & Cocourou \\
& & Non-spherical & Yellow & Cotama \\
Lobi & Pwan & Non-spherical & Yellow & Ganpwan \\
\hline
\end{tabular}




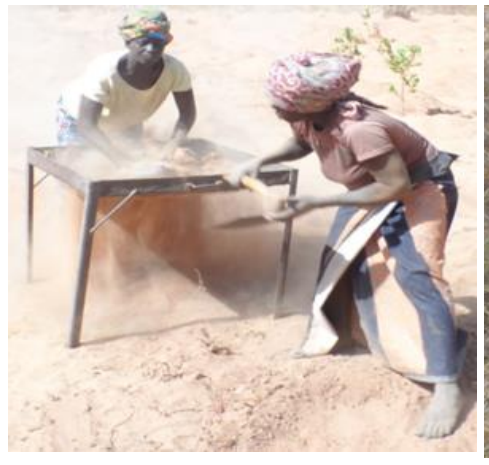

Sifting of tuber piles: Upper basin

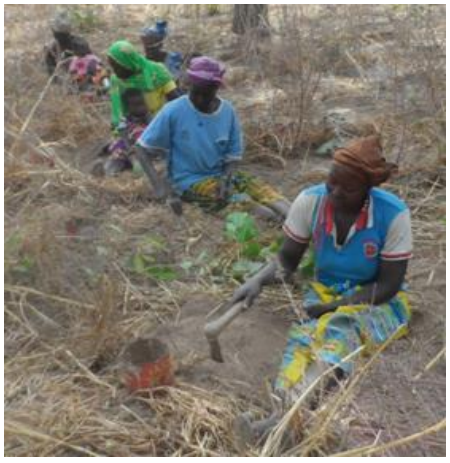

Harvesting with picks and fingers: Cascade

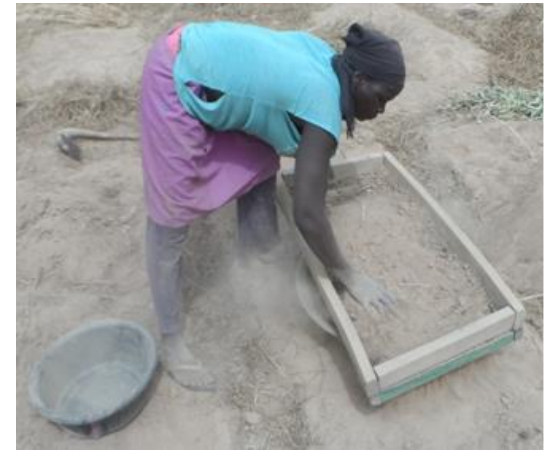

Sifting of tuber piles: Southwest

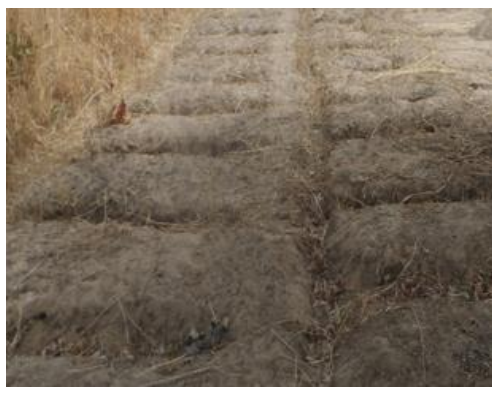

Tiger Nut drained board in Lorépéni

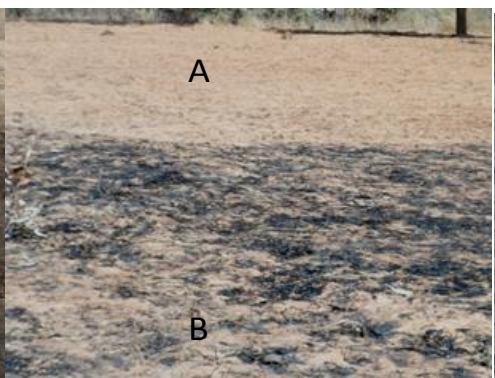

Koloko Tiger Nuts board. A: unburned; B

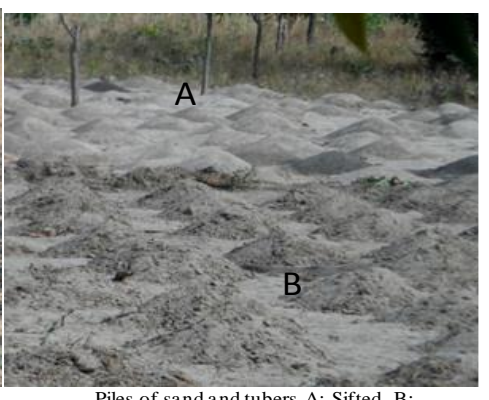

Piles of sand and tubers A: Sifted, B: Unsifted.

Figure 3: Photos of harvesting techniques by region.

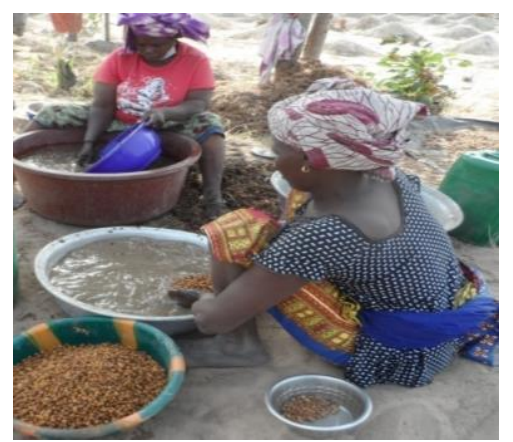

Koloko water winnowing

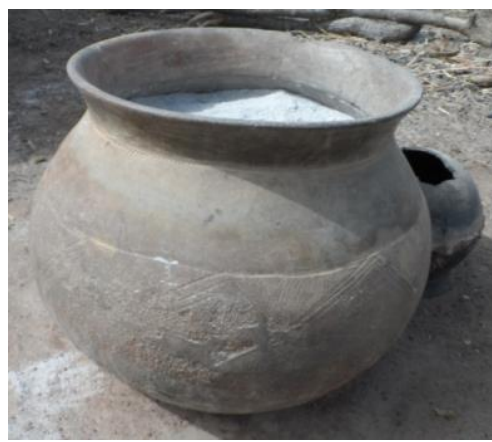

Storage in a jar with the help of ashes Tiankoura

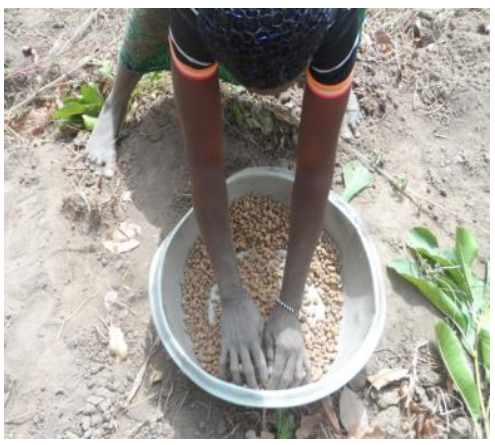

Mangodara tuber rubbing

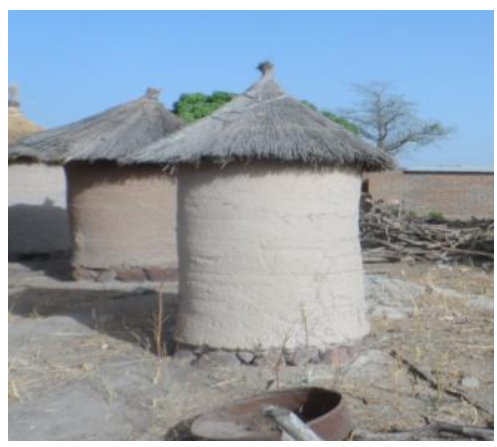

Conservation in attics sand related Ouéléni

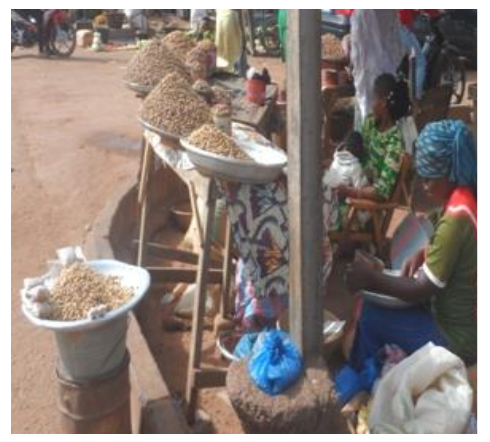

Sale of Banfora sweet pea tubers

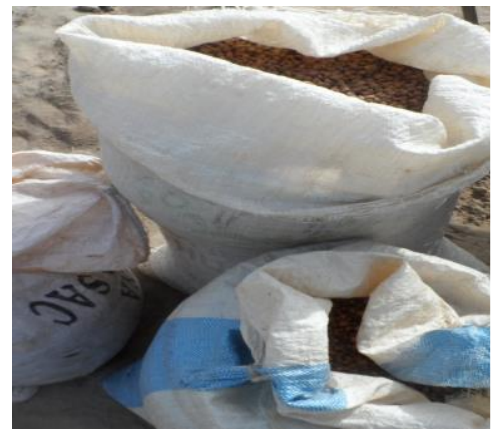

Conservation in Koloko bags

Figure 4: Pictures of post-harvest treatment of tubers and preservatives. 


\section{DISCUSSION}

\section{Determination of the nutsedge growing area}

The survey showed that the Sudanian zone with an annual rainfall of between 900 and $1200 \mathrm{~mm}$ is the main yellow nutsedge production zone in Burkina Faso. This zone includes the Hauts-bassins, the Cascades and the South-West region. The absence of nutsedge culture in the Sahelo-Sudanian and Sahelian zone in Burkina Faso would be linked to climatic conditions. Indeed, the Sudanian zone being very watered, it is favourable to the cultivation of tuberous plants compared to other plants (Traoré, 2014; Kiébré, 2016; Sawadogo, 2016). According to Dodet et al., (2006a), the geographical distribution of the species can be linked to variations in climatic and edaphic factors. In addition, other authors have found that the plant is widespread in tropical and temperate areas and also occurs in colder regions (Milczak et al., 2001; Larridon et al., 2011).

This distribution of yellow nutsedge production could also be explained by sociocultural reasons. In fact, $97 \%$ of the respondents affirmed that the maintenance of the culture until now is due to the fact that the nutsedge is a traditional plant ingrained in the culture of the populations of these regions.

The variation in the number of accessions according to the communes would be explained by the variation in the intensity of production according to the localities. In fact, the production of yellow nutsedge is very intense in the communes of Koloko, Kangala, and Oueleni where in each concession it is produced.

Ninety-seven per cent of the people who cultivate yellow nutsedge are women, which confirms that it is an exclusively female activity. In fact, women are the most suitable person to preserve and transmit faithfully the traditions of a society from one generation to the next one. In general, in yellow nutsedge production sites, a seven-year-old girl already has a few feet of yellow nutsedge in her name. Similar results were found by Ouédraogo et al. (2016a) and Sawadogo et al. (2006) on okra. This could also be explained by the tedious nature of the production of yellow nutsedge, which requires more than one of them. According to Sissoko et al. (2011a) in Mali, the harvest of cultivated yellow nutsedge can extend over 4 months, more precisely from December to March, and a woman can use 2 hours to harvest an area of $40 \mathrm{~m}^{2}$. The low rate of men $(3 \%)$ that has emerged in recent years supports the hypothesis that nutsedge is a woman's crop. The renewed interest in recent years by men in yellow nutsedge is due to the economic value of production. Similar results were found by Ouédraogo et al. (2016b), on okra and Alou et al. (2008) on yellow nutsedge in Mali.

The origin of this crop according to the majority of producers is Burkina Faso, but Ghana and Mali were cited by a few producers. These results could be explained by the origin of the ethnic groups holding the seeds, which is the case of Goin, coming from Ghana, and part of the Senoufos, which are found in Mali. For several authors, the origin of $C$. esculentus is uncertain. For some authors, C. esculentus originates from the Old World (DAISIE, 2014; Acevedo-Rodríguez and Strong, 2012). However, other authors consider it to originate from tropical and subtropical regions around the world, including Africa, Asia, Europe and North America (Govaerts, 2014; USDA-ARS, 2014). Recent studies have shown that sweet pea is of tropical African origin (De Castro et al., 2015).

\section{Peasant nomenclature of nutsedge (Cyprus esculents $\mathbf{L}$.)}

Farmers use several criteria to characterize nutsedge, including tuber color, tuber shape, membership of ethnic groups and sexual dimorphism. Thus, in the district of Koloko, Kangala, Ouéléni, Kangalba, Banfora, Mangodara, Lorépéni, the shape and color of the tuber are used by growers to characterize morphotypes. In Goins, in Banfora, the growers use two criteria, namely the colour of the tubers and the phenomenon of sexual dimorphism to clearly identify the nutsedge morphotypes. Sexual dimorphism is the set of more or less marked morphological differences between male and female individuals of the same species. (http://fr.wikipedia.org). Indeed, 
the yellow and spherical tubers are called "mou tiama" which means "tubers". Similarly, naming based on sexual dimorphism has also been noted by. Nanema et al. (2010) on Sudanese potato. According to Missihoun et al. (2012) and Nebié (2013), the nomenclature of local sorghum is mainly based on plant parts such as panicle type, grain colour, glume colour and stem flavour.

Indeed, the black tubers considered spherical are called "mou bulilé". These results corroborate those of Daouda et al. (2002) in Niger where farmers distinguish the large tuber nutmeg consisting of three morphotypes and four morphotypes of the small tuber nutmeg, of which, 'Ja aya' are small brown tubers; 'Bahilata' are brownish; 'Baka aya' are black, and 'Koima' or 'Fatsama' are black and very oleaginous.

According to Dodet et al. (2006b), in French, the plant is sometimes called yellow nutsedge sultan, almond, acorn, tiger nut or sweet pea because of its tubers with a slightly sweet hazelnut flavor. In Spanish-speaking countries, the invasive character of the plant is used to call it "chufa", In English-speaking countries, C. esculentus is called yellow nutsedge, yellow nutgrass, watergrass, earth almond, groundnut, tiger nut, zulu nut, rush nut, duck potato and edible rush, referring either to its resemblance to grasses or to the edible character of its tubers. In Tiankoura, it is the ethnic group affiliation, which is used by the peasants, thus, the spherical tubers are called "lobipwan" which means Lobi Nut and the non-spherical tubers "ganpwan" which means Gan nutsedge. The mosse of the central plateau use the invasive character of the wild tiger nut to call it "sanansanga", those of the north use the sweet flavor of the tubers by calling it "moonma", however they call the cultivated tiger nut "tchongon" and find no link between the cultivated and wild tiger nut.

\section{Cultivation practice}

The variability of the soils encountered in the survey shows that yellow nutsedge is a crop adapted to several types of soil. $C$. esculentus is reported to be present in a wide variety of soil types depending on the geographical location of the observations made.

The monoculture observed in yellow nutsedge could be explained by the invasive character of the crop. Indeed, although it is the variety cultivated, cultivation in association with other crops could lead to a reduction in yield of the latter. The deep ploughing used, often ranging from 25 to $35 \mathrm{~cm}$, is interesting for taproot or tuberous plants. However, the typical draining bed of the nutsedge in the southwest consists of cleaning up soil that is too wet to make it workable. The removal of excess water will then promote soil aeration, its physical constitution for better root penetration. This confirms that the cultivated nutsedge does not like a very wet soil, edges of rivers, it has adapted to less humid environments like most other crops after domestication by man. The rotation cropping system observed in this part of Burkina confirms the previous hypothesis. This crop, which is characterized by limited agricultural investment because it uses rudimentary means to exploit the soil, a lack of investment in production leading to a lack of soil fertilization policy and low productivity, is an extensive form of agriculture. However, nutsedge is intensively cultivated in Spain (Pascual, 2002).

The myth during sowing about the germination of tubers at the feet of the senoufos can be explained by the fragility of the seedlings, the rapidity of tuber germination and so that the tubers do not sink too deeply. The sowing period, in the Hauts-bassin and Cascades in mid-August, could be explained by several reasons, nutsedge is a crop neglected and practiced by women, the length of its development cycle and the length of the rainy seasons. Li et al. (2001) have shown that tuber germination is strongly reduced in compacted soils and that individuals growing at $100 \%$ moisture produce significantly more tubers and vegetative material than those growing at $50 \%$ moisture.

Harvesting techniques are similar by regions and not by ethnicity. The burning of the aerial part has two functions: the first is the cleaning of the plot and the second is the provision of the mineral elements contained in 
the ashes to the plants. The following steps, i.e. threshing, heaping and sieving, are specific to sweet pea production. A significant amount of the production is lost due to the fact that the instruments used are not well adapted. In addition, this crop is very degrading to the soil structure and can lead to the death of the woody plants present in the fields (Larwanou et al., 2010; Sissoko et al., 2011b). Sweet pea tubers are used for food and medicinal purposes by growers. The yellow nutsedge milk produced by the Lobis for orphans would be an organic bottle containing the nutrients necessary for the maintenance and growth of infants. The tuber of yellow nutsedge is an important source of protein. The treatment of disorders of lactine secretion and sexual weakness are due to the high content of mineral and organic elements. For several authors, sweet pea has high fiber content, an inexhaustible source of magnesium which is responsible for more than 300 necessary biochemical interactions of the body Indeed, the yellow nutsedge oil has nothing to envy the traditional oil. It can be observed that, in treating these tubers, the food is very dissimilar, but full of healthy power and by its high levels of oleic acid (mono unsaturated); this lipid is perfect to nourish the skin and prepare it for external aggressions. Nutsedge tubers have a by-product potential that could lead to economic and social development of producers and the Burkinabe population in general.

\section{Conclusion}

The study identified three production areas for yellow nutsedge Cyperus esculentus L. in Burkina Faso. Producer accessions are obtained by inheritance and the sweet pea grown would come from Burkina, Mali or Ghana. Farmers confuse wild and purple nutsedge and find no link between cultivated and wild nutsedge. Farmers use morphological characteristics to characterize sweet pea and there is variability in traditional practices for growing the species between production areas. The traditional methods of nutsedge cultivation degrade not only the health of the farmers but also the environment. After a rigorous characterization of the accessions from an agromorphological and molecular point of view, modern methods of production of this noble crop should be found.

\section{COMPETING INTERESTS}

The authors declare that they have no competing interests.

\section{AUTHORS' CONTRIBUTIONS}

MS, NS, MHO and ON designed the research. SY and NS wrote the manuscript and performed the experiments. SY, RKN and ZK, analyzed the data. All authors read and approved the final manuscript.

\section{ACKNOWLEDGEMENTS}

This study was made possible by the support of several individuals, to whom we would like to express our gratitude. In particular, the sweet pea growers in the three production zones, the agents of the Ministry of Agriculture and the teaching staff of the Biosciences Laboratory of the Joseph ki-Zerbo University.

\section{REFERENCES}

Acevedo-Rodríguez P, Strong MT. 2012. Catalogue des plants de semences des Antilles. Smithsonian Contributions to Botany, 98: 1192.

Alou AK. 2008. Plan d'affaires de la fédération SA'A de Maradi pour la commercialisation du souchet à l'export 2009-2013. Extrait étude de marché, Maradi, $14 \mathrm{p}$.

Bamishaiye EI, Bamishaiye OM. 2011. Tiger nut: as a plant, its derivatives and benefits. African Journal of Food, Agriculture, Nutrition and Development, 11: 5157-5170. DOI: 10.4314/ajfand.v11i5.70443.

DAISIE. 2014. Réalisation d'inventaires d'espèces exotiques envahissantes en Europe. Portail européen des espèces exotiques envahissantes, P7. www.europe-aliens.org/default.do.

Daouda T, Dine S, Assoumane I, Gallo B. 2002. Plan d'actions sur la filière souchet, version final. PAFS, 53p. 
De Castro O, Gargiulo R, Del Guacchio E, Caputo P, De Luca P. 2015. A molecular survey concerning the origin of Cyperus esculentus (Cyperaceae, Poales): two sides of the same coin (Weed vs. Crop). Annals of Botany, 115: 733-745. DOI: https://dx.doi.org/10.1093\%2Faob\%2Fm cv001.

Defelice MS. 2002. Yellow nutsedge Cyperus esculentus L.: snack food of the Gods. Weed Technology, 16: 901-907. DOI: https://doi.org/10.1614/0890-037X

Dodet M. 2006. Diversité génétique et phénologie de Cyperus-esculentus L. (Cypéracées) pour une gestion intégrée de l'espèce dans les cultures de haute lande. Thèse en Ecologie, environnement, Université de Bourgogne, 226p.

Govaerts R. 2014. Liste de Contrôle Mondiale de Cyperaceae. Royal Botanic Gardens : Londres-Royaume-Uni.

http://apps.kew.org/wcsp/

Judd C, Kellog S. 2002. Relations Phylogéniques Entre les Angiospermes: Botanique Systématique-Une Perspective Phylogénétique (ed). De Boeck Université.

Kabré NV, Sawadogo B, Kiebré M, Kiébré Z, Nanema K R, Bationo KP. 2019. Estimates of phenotypic diversity and genetic parameters of Hibiscus cannabinus L. grown in Burkina Faso. Int. J. Biol. Chem. Sci., 13(4): 1903-1917. DOI:

https://dx.doi.org/10.4314/ijbcs.v13i4.1.

Kiébré Z. 2016. Etude de la diversite genetique d'une collection de caya blanc (Cleome Gynandra L.) du Burkina Faso. Thèse Unique de Doctorat, Université de Ouagadougou, Burkina Faso, 139 p.

Larridon I, Reynders M, Huygh W, Judd C, Kellog S. 2011. Affinities in C3 Cyperus lineages (Cyperaceae) revealed using molecular phylogenetic data and carbon isotope analysis. Botanical Journal of the Linnean Society, 167: 1946. DOI: doi.org\%2F10.1111\%2Fj.10958339.2011.01160

Larwanou M, Oumarou I, Laura SI, Danguimbo O, Eyog-Matig. 2010.
Pratiques sylvicoles et culturales dans les parcs agroforestiers suivant un gradient pluviométrique nord-sud dans la région de Maradi au Niger. Tropicultura, 28: 115-122.

Li B, Shibuya T, Yogo Y, Hara T, Yokozawa M. 2001. Interclonal differences, plasticity and trade-offs of life history traits of Cyperus esculentus in relation to water availability. Plant Sp. Biol., 16:193-207.

Nanema KR. 2010. Ressources génétiques de Solenostemon rotundifolius (Poir.) J. K. Morton du Burkina Faso : système de culture, variabilité agro-morphologique et relation 119 phylogénétique entre les différents morphotypes cultivés au Burkina. Thèse Unique, Université de Ouagadougou, Burkina Faso, 122p.

Nebié B, Nanema KR, Bationo/Kando P,Traoré RE, Labeyrie V, Sawadogo N, Sawadogo M, Zongo JD. 2013. Variation des caractères agromorphologiques et du brix d'une collection de sorghos à tige sucrée du Burkina Faso. Int. J. Biol. Chem. Sci., 7(5): 1919-1928. DOI: http://dx.doi.org/10.4314/ijbcs.v7i5.12.

Milczak M, Wiercinski J, Sawicki B. 2001. Nutritious value of Cyperus esculentus L. from cultivation in the natural conditions of the Lublin upland. Annales Universitatis Mariae Curie Sklodowska, Sectio E, Agricultura, 56: 43-48.

Missihoun AA, Agbangla C, AdoukonouSagbadja H, Ahanhanzo C, Vodouhe R. 2012. Gestion traditionnelle et statut des ressources génétiques du sorgho (Sorghum bicolor L. Moench) au NordOuest du Bénin. Int. J. Biol. Chem. Sci., 6(3): $\quad 1003-1018 . \quad$ DOI: http://dx.doi.org/10.4314/ijbcs.v6i3.8.

Ouedraoga H. 2016. Etude de la diversité génétique des gombos [abelmoschus esculentus (1.) Moench] cultives au Burkina Faso. Thèse Unique de Doctorat, Université de Ouagadougou, Burkina Faso, 127 p.

Pascual EB. 2002. Noix du tigre (Cyperus esculentus L. var. Sativus Boeck.), Une culture

typiquement 
valencienne. Agricultura, $\quad$ Revista Agropecuaria, 71(838): 294-298.

Pascual-Seva N, San Bautista A, LópezGalarza SV, Maroto JV, Pascual B. 2013. 'Alboraia' Bonrepos': the first registered Chufa (Cyperus esculentus L. var. sativus Boeck.) cultivars. Hort. Science, 48: 386389.

DOI :

http://hdl.handle.net/10251/28261.

Sawadogo N. 2015. Diversité génétique des sorghos à grains sucrés [Sorghum bicolor (L.) MOENCH] du Burkina Faso. Thèse Unique de Doctorat, Université de Ouagadougou, Burkina Faso, 185 p.

Sawadogo N, Nibie B, Kiebre M, Nanema KR, Traore RE, Naoura G, Sawadogo M, Zongo JD. 2014. Caractérisation agromorphologique des sorghos à grains sucrés (Sorghum bicolor (L.) Moench) du Burkina Faso. Int. J. Biol. Chem. Sci., 8(5): 2183-2197. DOI: http://dx.doi.org/10.4314/ijbcs.v8i5.22.

Sawadogo M, Balma D, Zombre G. 2006. Expression de différents écotypes de gombo (A. esculentus (L.)) au déficit hydrique intervenant pendant la boutonnisation et la floraison. Biotechnologie, Agronomie, Société, Environnement, 10(1): 43-54. DOI: https://doi.org/10.4013/BASE.2013.101. 04

Sissoko. 2011. Mise au point de matériels de récolte pour la promotion de la culture du pois sucré (Cyperus esculentus L.). Les Cahiers de l'Economie Rurale, (12): 2834.

Traoré ER. 2014. Etude de la diversité du taro (Colocasia esculenta (L.) Schott.) : Cas d'une collection du Burkina Faso et d'une collection internationale. Thèse Unique, Université de Ouagadougou, Burkina Faso, 181p.

USDA-ARS. 2014. Réseau d'information sur les ressources en matériel génétique (GRIN). Laboratoire national de ressources en matériel génétique, Beltsville-Maryland, États Unis. https://npgsweb.arsgrin.gov/gringlobal/taxon/taxonomysearc h.aspx. 